Original research article

\title{
The attitudes of neonatological nurses to providing perinatal palliative care
}

\author{
Miroslava Kachlová *, Radka Bužgová \\ University of Ostrava, Faculty of Medicine, Department of Nursing and Midwifery, Ostrava-Vitkovice, Czech Republic
}

\begin{abstract}
Perinatal palliative care is provided to newborns in cases when it has been decided to discontinue life-saving treatment or life-prolonging treatment. The aim is to focus on honoring the best values of a patient and to maximize the quality of his or her life. These newborns live under life-limiting or life-threatening conditions. This study focuses on the attitudes of nurses to providing perinatal palliative care. It aims to identify factors that affect the level of care provided by nurses on a neonatological intensive care unit (NICU) in the Czech Republic, whilst also analysing barriers and facilitators. A quantitative study was performed with the use of the standardized questionnaire NIPCAS (Neonatal Palliative Care Attitude Scale) adapted to Czech language. The research showed that the majority of participants perceive the practice of palliative care for dying child positively. A barrier was identified in the form of the environment where the palliative care is provided. The implementation of palliative care should include awareness and reassurance of parents that the medical team will continue to provide the best care to their child. Parents should be actively involved in making decisions with respect to their emotional state and cultural and religious beliefs. That is why specialized educational courses should exist to provide information about neonatological palliative care.
\end{abstract}

Keywords: NICU; Nurses; Nursing care; Perinatal palliative care

\section{Introduction}

Perinatal palliative care is provided to newborns in cases when it has been decided to discontinue life-saving treatment or life-prolonging treatment. It includes newborns that have to be hospitalized in intensive care units, often in connection with immaturity of the child, complications during labour or serious infections (Kiman and Doumic, 2014). The neonatal mortality in the Czech Republic in the 1990s was quite high in comparison to other developed countries. Nevertheless, over the last few years it has been among the lowest in the world (Ratislavová and Hálek, 2019). Nowadays, an average of 450 Czech women a year experience the loss of their child (Ratislavová, 2016). The aim of perinatal palliative care is to focus on honoring the best values of a patient and to maximize the quality of his or her life. These newborns live under life-limiting or life-threatening conditions. An inseparable part of the treatment is also the support of the child's family. This support should be highly individual and should last as long as it is necessary (Fortney and Steward, 2014; Kiman and Doumic, 2014; Marchuk, 2016). The idea of perinatal palliative care is not new. It has been developing since the 1980s, especially in the USA (Balaguer et al., 2012; Whitfield et al., 1982). Despite that, there are still some inconsistencies between the attitudes towards neonatal palliative care and its provision. The correct implementation of perinatal palliative care into practice requires multidisciplinary effort, cooperation and a coordinated plan (Catlin and Carter, 2002; Kenner et al., 2015). Doctors and the child's parents make the decision about palliative care. However, nurses are extremely close to the parents during this period and they should participate in providing optimal conditions as well as coordinating complex care (de Castro de Oliviera et al. 2018; Reid et al., 2011).

In order to be able to do the job adequately, the nurses should have a clear view of the issue of death and suffering, and should know their own values and motivations for their work, attitudes and beliefs. The aim of the study was to determine the attitudes of nurses to perinatal palliative care and to identify the factors that influence these attitudes - in order to analyse the barriers and facilitators of nurses in providing perinatal palliative care to patients.

\section{Materials and methods}

The study is designed as a quantitative study with the use of the standardized questionnaire NIPCAS (Neonatal Palliative Care Attitude Scale) by Kain et al. (2009). It focuses on the attitudes of neonatological nurses to palliative care. The questionnaire was translated from English to Czech. The translation was assigned to two translators, and the resulting versions were re-

\footnotetext{
* Corresponding author: Miroslava Kachlová, University of Ostrava, Faculty of Medicine, Department of Nursing and Midwifery, Syllabova 19, 70300 Ostrava-Vítkovice, Czech Republic; e-mail: miroslava.kachlova@osu.cz http://doi.org/10.32725/kont.2021.036 
viewed at a joint meeting of 10 neonatology nurses working in the ICU for newborns. The wording of the translated items has been adapted to the professional level and language of health professionals. Subsequently, a pilot survey was carried out at the neonatological ICU FNO, on the basis of which: minor verbal changes were made to 3 questionnaire items, the possibility of expressing one's own opinion on the researched issue was added, and the respondent's religion item was also included. The final form of the tool was consulted with a scientific expert in the field of nursing.

The questionnaire consists of 35 items -8 of them are demographic information, 26 review the attitudes of nurses to perinatal palliative care, and one is an open answer item. The review items use a Likert scale in which " 1 " means "Strongly agree" and "5" means "Strongly disagree". For statistical processing, the " 1 " and " 2 " options of the Likert scale were combined as positive attitudes and options " 4 " and " 5 " as non-positive. Option " 3 " was considered neutral.

The items that focus on nurses' attitudes are divided into four subscales: "organization", "resources", "doctors" and "experience and attitudes of nurses". The subscale "organization" is focused on the environment where palliative care is provided. The environment can make the practice easier or the other way around - it can cause obstacles. The subscale "resources" aims to evaluate nurses' opinions. They reveal what they think about the amount of time parents are given to make decisions about palliative care, consultations, whether the number of employees is sufficient, and standards and instructions about providing palliative care. The subscale "doctors" examines questions about morality and ethics - whether nurses have an impact on how individual technologies are used and if parents' voices are heard. The subscale "experience and attitudes of nurses" looks at nurses' experience with palliative care, their views and beliefs in the questions of patients' death.

The measurement tool NiPCAS is designed to evaluate six factors in providing perinatal palliative care - these factors are considered facilitators or barriers. The first factor evaluates the base and the environment for giving palliative care. This is examined by 10 out of the 26 items focused on nurses' attitudes. The second factor consists of four items and it shows how personal views on death affect the care that nurses provide. The third factor, also consisting of four items, evaluates the feeling of personal failure towards the provision of treatment. The fourth factor evaluates two items - the discomfort of the staff who is asked by parents to continue to take care of child's life, even though the prognosis is very unfavourable. The fifth factor consists of three items: education, soothing pain while dying, and whether or not palliative care is considered as important as curative care. The sixth factor consists of two items that look at the support of palliative care in society and nurses' traumas from looking after a dying child. The research sample consists of nurses working at a neonatological ICU. The criteria for being included in the sample was a minimum of one year experience at a neonatological ICU. 12 perinatological centers in the Czech Republic were contacted. The communication with individual centers was realized by talking to head nurses of neonatological departments. The participation in the research was voluntary and anonymous. Only 5 perinatology centers took part in the research, 12 in total were contacted (this could be due to the first wave of the Covid-19 pandemic). The data was collected from April 2020 to September 2020 and it was processed in Microsoft Office Excel. Common statistical techniques were used - frequency tables, median, arithmetical mean, determinative derivation. For the evaluation of the difference between subscales according to selected factors, the
Kruskal-Wallis test was used for most of the groups, and the Mann-Whitney test for two selections. To find out the relationship between subscales, the Spearman correlation coefficient was used. Statistical tests were evaluated according to a significance level of $5 \%$.

\section{Results}

\section{Sociodemographic characteristics of the sample}

Our questionnaire consisted of 109 respondents. The total number of respondents was 115, but 6 questionnaires had to be eliminated due to incomplete or incorrect completion. The majority of respondents were from the perinatological center in Brno (37.6\%) and the fewest from the perinatological center in Most (9.2\%) - Table 1. Only two respondents out of 109 were men (1.8\%), the rest were women (98.2\%). The largest age bracket was $41-50$ years (40\%). Nearly half of the examined sample were nurses who specialized in intensive care. A large number of respondents had achieved secondary education (48.6\%) and work as ward nurses (95.4\%). Regarding religion, $83.5 \%$ indicated that they are not a part of any church.

\section{Table 1. Sociodemographic characteristics of respondents}

\begin{tabular}{|c|c|c|}
\hline & Number & $\%$ \\
\hline \multicolumn{3}{|l|}{ Sex } \\
\hline Women & 107 & 98.2 \\
\hline Men & 2 & 1.8 \\
\hline \multicolumn{3}{|l|}{ Age } \\
\hline $20-30$ & 18 & 16.5 \\
\hline $31-40$ & 32 & 29.4 \\
\hline $41-50$ & 43 & 39.5 \\
\hline Over 50 years & 16 & 14.7 \\
\hline \multicolumn{3}{|l|}{ Education } \\
\hline High school & 53 & 48.6 \\
\hline Higher vocational school & 17 & 15.6 \\
\hline Bachelor's degree & 29 & 26.6 \\
\hline Master's degree & 10 & 9.2 \\
\hline \multicolumn{3}{|l|}{ Specialization } \\
\hline Yes & 53 & 48.6 \\
\hline No & 45 & 41.3 \\
\hline Studying & 11 & 10.1 \\
\hline \multicolumn{3}{|l|}{ Religious beliefs } \\
\hline Yes & 18 & 16.5 \\
\hline No & 91 & 83.5 \\
\hline \multicolumn{3}{|l|}{ Perinatological centre } \\
\hline Ostrava & 21 & 19.3 \\
\hline Brno & 41 & 37.6 \\
\hline Zlín & 14 & 12.8 \\
\hline Most & 10 & 9.2 \\
\hline Praha & 23 & 21.1 \\
\hline \multicolumn{3}{|c|}{ Length of neonatal nursing experience } \\
\hline $1-5$ years & 25 & 22.9 \\
\hline $6-10$ years & 20 & 18.4 \\
\hline $11-15$ years & 22 & 20.2 \\
\hline Over 15 years & 42 & 38.5 \\
\hline \multicolumn{3}{|l|}{ Working time } \\
\hline Full & 89 & 81.7 \\
\hline Partial & 20 & 18.4 \\
\hline \multicolumn{3}{|l|}{ Job position } \\
\hline Nurse & 104 & 95.4 \\
\hline Nurse manager & 5 & 4.6 \\
\hline
\end{tabular}




\section{The evaluation of nurses' attitudes towards perinatal palliative care}

The results of the NiPCAS questionnaire are described in individual subscales. The average of the subscale "organization" was 1.95 ( $S D=0.57$ ); it shows the level of consensus with the items represented in each scale. Most respondents (88.1\%) agreed that parents are informed about the possibility of palliative care in the case that a diagnosis that excludes curative care is given (Table 2). The majority of respondents (83.5\%) also stated that parents are included in making decisions about their dying child.

The average of subscale "resources" was $2.55(\mathrm{SD}=0.71)$ and it expresses the rate of agreement with the statements that relate to the presence of resources supporting palliative care on the department. Only 33.9\% of respondents stated that the environment for providing palliative care to dying children and their families is ideal. Nearly one fourth (23.9\%) disagreed that if there is a dying baby on the department, a nurse has enough time to spend with the family of the child. The subscale "clinicians" gave an average of $2.11(\mathrm{SD}=0.70)$. This average indicates the level of agreement with the nurses' opinion that physicians continue to use technological life support beyond the child's comfort level $(80.7 \%)$ and that doctors are asked by parents to continue prolonging their children's lives (60.6\%).

The subscale of questions aimed at experience and attitudes of nurses produced an average of $2.63(\mathrm{SD}=0.38)$. Almost all respondents (97.2\%) reached an agreement that it is important to them to provide children with relief from pain. Also, the majority of participants (94.5\%) agreed with the statement that palliative care is as important as curative care. A significant number (91.7\%) also stated that it is very impor-

Table 2. Attitudes of nurses to palliative care (in \%)

\begin{tabular}{|c|c|c|c|}
\hline & Agree & Disagree & Unsure \\
\hline \multicolumn{4}{|l|}{ Subscale "experiences and attitudes of nurses" } \\
\hline Palliative care is as important as curative care in the neonatal environment & 94.5 & 3.7 & 1.8 \\
\hline I have had experience of providing palliative care to dying babies and their families & 60.6 & 31.2 & 8.3 \\
\hline I feel a sense of personal failure when a baby dies & 29.4 & 53.2 & 17.0 \\
\hline There is support for neonatal palliative care in society & 51.4 & 4.6 & 44.0 \\
\hline My previous experiences of providing palliative care to dying babies have been rewarding & 69.7 & 11.0 & 19.3 \\
\hline When babies are dying in my unit, providing pain relief is a priority for me & 97.2 & 0.9 & 1.8 \\
\hline I am often exposed to death in the neonatal environment & 35.8 & 56.9 & 7.3 \\
\hline Palliative care is necessary in neonatal nursing education & 91.7 & 2.8 & 5.5 \\
\hline Caring for dying babies is traumatic for me & 67.9 & 22.9 & 9.2 \\
\hline $\begin{array}{l}\text { I have received in-service education that assists me in supporting and communicating with parents of } \\
\text { dying babies }\end{array}$ & 37.6 & 58.7 & 3.7 \\
\hline My personal attitudes about death affects my willingness to deliver palliative care & 35.8 & 29.4 & 34.9 \\
\hline Palliative care is against the values of neonatal nursing & 8.3 & 69.7 & 22.0 \\
\hline There is a belief in society that babies should not die, under any circumstances & 30.3 & 37.6 & 32.1 \\
\hline Curative care is more important than palliative care in the neonatal intensive care environment & 20.2 & 47.7 & 32.1 \\
\hline \multicolumn{4}{|l|}{ Subscale "organization" } \\
\hline The medical staff support palliative care for dying babies in my unit & 78.0 & 14.7 & 7.3 \\
\hline In my unit, parents are involved in decisions about their dying baby & 83.5 & 7.3 & 9.2 \\
\hline $\begin{array}{l}\text { In my unit, when a diagnosis with a likely poor outcome is made, parents are informed of palliative care } \\
\text { options }\end{array}$ & 88.1 & 2.8 & 9.2 \\
\hline In my unit the team expresses its opinions, values and beliefs about providing care to dying babies & 64.2 & 15.6 & 20.2 \\
\hline $\begin{array}{l}\text { All members of the health care team in my unit agree with and support palliative care when it is } \\
\text { implemented for a dying baby }\end{array}$ & 82.6 & 4.6 & 12.8 \\
\hline \multicolumn{4}{|l|}{ Subscale "resources" } \\
\hline The physical environment of my unit is ideal for providing palliative care to dying babies & 33.9 & 51.4 & 14.7 \\
\hline $\begin{array}{l}\text { My unit is adequately staffed for providing the needs of dying babies requiring palliative care and their } \\
\text { families }\end{array}$ & 52.3 & 25.7 & 22.0 \\
\hline When a baby dies in my unit, I have sufficient time to spend with the family & 60.6 & 15.6 & 23.9 \\
\hline There are policies/guidelines to assist in the delivery of palliative care in my unit & 56.9 & 18.3 & 24.8 \\
\hline When a baby dies in my unit, counseling is available if I need it & 61.5 & 25.7 & 12.8 \\
\hline \multicolumn{4}{|l|}{ Subscale "clinicians" } \\
\hline In my unit, the staff go beyond what they feel comfortable with in using technological life support & 80.7 & 3.7 & 15.6 \\
\hline In my unit, staff are asked by parents to continue life-extending care beyond what they feel is right & 60.6 & 17.4 & 22.0 \\
\hline
\end{tabular}


tant for neonatological nurses to pay special attention to education about palliative care. Nevertheless, the research showed that only $37.6 \%$ of participants went through complementary study that helps with how to support and communicate with parents of a dying child. $69.7 \%$ of respondents agreed with the statement that previous experience with a dying child is a benefit when providing palliative care, but at the same time $67.9 \%$ stated that this experience is traumatic for them. In our research, $29.4 \%$ of nurses consider the death of a child to be their personal failure. The feeling of being often exposed to death emerged among $35.8 \%$ of nurses.

More than half of the respondents $(60.6 \%)$ have experience with providing palliative care to children and their families. In the opinion of $51.4 \%$ of respondents, there is a support for perinatal palliative care in society. Only $8.3 \%$ of respondents agree that palliative care is against neonatological values. In a similar way, $20.2 \%$ believe that curative care in intensive care in neonatology is more important than palliative care. The opinion that society believes that children should not die under any circumstances is supported by $30.3 \%$ of respondents. About the same number of respondents, $35.8 \%$, agree with the item "My personal attitude about death affects my willingness to deliver palliative care". Open answer boxes contained the opinions that "there should be a room to have conversations with parents; it is not always possible to talk by the bed due to presence of other children and their parents". Another nurse wrote: "I think a large part of palliative care that is provided in the ICU could take place at home as part of home hospice care. Including bidding a baby farewell." Other open answers related to the suggestion of more seminars and training courses (where nurses could learn more about how to communicate with parents of a dying child), or the creation of a national standard that would pass for an adequate framework of palliative care. Two respondents used the open answer box to praise the cooperation with the Prague Guidance Centre (Centrum provázení Praha).

\section{Comparison of nurses' attitudes according to certain characteristics}

Nurses' attitudes in individual subscales were evaluated according to age, experience, specialization, education and religion. A statistically significant difference was discovered according to age $(p=0.0157)$ in the subscale experience and attitudes of nurses, the highest value was discovered among the youngest category -20 to 30 years (Table 3 ). This value agrees that palliative care in neonatology is very important, but participants within this category have less experience with death, dying and providing children and their parents with palliative care. A significant difference was discovered in the subscale experience according to the length of practice. The highest value was discovered among the category with less experience -0 to 5 years. This fact correlates with the previous result - the youngest age group often belongs to the category with the shortest experience. Even this statistical value confirms the agreement with the importance of palliative care. This comparison showed a descending trend according to experience. In specialization, a significant difference $(p=0.0012)$ was found in the subscale "experience and attitudes of nurses", and nurses with no specialization received the highest value. Higher values suggest that nurses who underwent specialist education are more likely to be experienced in the field. These nurses agree that palliative care in the neonatological department is as important as curative care and they do not feel as though they have failed if a baby dies. In education, no significant difference in any subscale was found, and the same can be said for religion.

A statistically significant relation was found between subscale resources and organization with the use of Spearman's correlation coefficient (Table 4). Individual items of the subscale "organization" (the support of palliative care, providing information to parents and involving them in making decisions about individual steps within palliative care) showed a higher presence of agreement, as well as the subscale "resources" (adequate teams exist in the department, there are some standards). Nurses agreed with the existence of support of palliative care in their department and with the support of parents. Nevertheless, the environment for providing palliative care to newborns and their parents is not ideal. Other subscales did not show any significant correlation.

\section{The evaluation of facilitators}

Another tool for an analysis of providing perinatal palliative care was the attempt to identify the presence of facilitators. The first factor - support of palliative care from the medical team, was assessed as a facilitator. The respondents were inclined to think that there is a sufficient and adequate team

Table 3. Comparison subscale "experiences and attitudes of nurses" by age, length of neonatal nursing experience and specialization

\begin{tabular}{|c|c|c|c|c|c|c|}
\hline & Number & Median & Mean & SD & Min-Max & $p$-value* \\
\hline \multicolumn{7}{|l|}{ Age } \\
\hline $20-30$ years & 18 & 2.9 & 2.9 & 0.31 & $2.0-3.4$ & \multirow{4}{*}{0.0157} \\
\hline $31-40$ years & 32 & 2.6 & 2.6 & 0.39 & $1.7-3.1$ & \\
\hline $41-50$ years & 43 & 2.6 & 2.6 & 0.38 & $1.9-3.5$ & \\
\hline Over 50 years & 16 & 2.6 & 2.5 & 0.35 & $1.7-3.3$ & \\
\hline \multicolumn{6}{|c|}{ Length of neonatal nursing experience } & \multirow{5}{*}{0.0116} \\
\hline $1-5$ years & 25 & 2.9 & 2.8 & 0.39 & $1.9-3.4$ & \\
\hline $6-10$ years & 20 & 2.7 & 2.7 & 0.46 & $1.7-3.5$ & \\
\hline $11-15$ years & 22 & 2.6 & 2.6 & 0.35 & $1.9-3.1$ & \\
\hline Over 15 years & 42 & 2.5 & 2.5 & 0.31 & $1.7-3.5$ & \\
\hline \multicolumn{6}{|l|}{ Specialization } & \multirow{4}{*}{0.0012} \\
\hline Yes & 53 & 2.5 & 2.5 & 0.31 & $1.7-3.5$ & \\
\hline No & 45 & 2.9 & 2.8 & 0.39 & $1.7-3.5$ & \\
\hline Studying & 11 & 2.6 & 2.6 & 0.46 & $1.9-3.4$ & \\
\hline
\end{tabular}




\begin{tabular}{|c|c|c|c|c|}
\hline$N=109$ & $\begin{array}{c}\text { Nurses' } \\
\text { experiences }\end{array}$ & Clinicians & Organization & Resources \\
\hline $\begin{array}{l}\text { Nurses' } \\
\text { experiences }\end{array}$ & 1 & & & \\
\hline Clinicians & 0.0725 & 1 & & \\
\hline Organization & 0.1232 & 0.1645 & 1 & \\
\hline Resources & 0.1212 & -0.0589 & $0.547^{*}$ & 1 \\
\hline
\end{tabular}

for providing palliative care to dying children and their families (52.3\%). More than half of the respondents (64.2\%) said that they can express their opinion, values and beliefs about providing palliative care in their department. The research has shown that $61.5 \%$ of nurses can seek professional help if needed, and $56.9 \%$ maintain that there are some standards concerning providing palliative care in their department. Most respondents $(83.5 \%)$ said that parents play a part in making decisions about their dying child. The second factor aimed at nurses' attitudes was confirmed as a facilitator as well. The participants stated (82.6\%) that their department supports palliative care. The third factor, which deals with the relation between the provision of palliative and curative care and the feeling of failure if a baby in neonatology dies, is also a facilitator. $94.5 \%$ of nurses do not think that curative care is more important and, if a baby dies with dignity, they do not see it as a failure. The fourth factor was focused on parents' requests to continue prolonging a child's life even if the prognosis is not favourable - this was confirmed in $60.6 \%$ of cases. In this case it does not make it a facilitator, but a barrier to providing palliative care. The fifth factor looks at the significance of education. The nurses stated $(91.7 \%)$ that it is necessary to educate the medical team in palliative care, $58.7 \%$ of respondents completed additional education. This factor was also evaluated as a facilitator while providing palliative care. The presence of the last facilitator was not confirmed $-51.4 \%$ of respondents agreed that perinatal palliative care is supported by society, but $67.9 \%$ of participants declared that providing this kind of care is traumatic for them.

As predicted, a barrier stating that the environment on NICU (where the palliative care is provided to children and their parents) is not ideal, was confirmed by $51.4 \%$ of respondents. Other barriers were expected to occur concerning cooperation and nurses' beliefs. The next anticipated barrier was that the majority of people in society think that children should not die under any circumstances, but it was not confirmed $-37.6 \%$ of respondents do not agree with this opinion, $30.3 \%$ agree, and $32.1 \%$ remain neutral.

\section{Discussion}

The research showed that the majority of participants have a positive approach to providing dying children with palliative care, and they do not perceive palliative care to be in conflict with neonatology. The majority also claim that, in terms of good quality care, it is important to ease a baby's pain if they are dying. After all, this is how the WHO describes palliative care - a concept that focuses on relieving a patient's suffering physical, psychological, social or spiritual (WHO, 2021). Under the terms of satisfying the psychological, social and spiritual needs it is important that parents have the opportunity to be present with a child at the time of passing away (Kain and Wilkinson, 2013). Nevertheless, the subscale "resources" revealed a problem in the environment where the palliative care is provided. Half of the respondents (51.4\%) stated that this is not ideal. Parents who go through such suffering should be able to get help, and other members of the family should have the opportunity to be present as well. It would be great if parents could get a glass of water, paper tissues, and disturbing elements were eliminated. Parents should also get enough space for privacy and as much time as they need (Hrdličková, 2019). Many of these things are not common in intensive care settings, sometimes it is not feasible to provide them. Special space has to be set aside for palliative care situations.

Studies dedicated to factors that have an impact on providing palliative care in intensive care units have been realized abroad as well - in Australia (Kain et al., 2009) and Taiwan (Chen et al., 2013). The respondents from the Australian research study mentioned that they lack silence in the NICU department. Palliative care is not sufficiently integrated into nursing education (Diel et al, 2013; Wool, 2013). It is desirable that palliative care is taken into consideration in educational programs and courses. This will lead to more professionals with a better understanding of the needs of children and their parents and to improved communication (Wool and Catlin, 2019). This is one of the conclusions from a report on children's palliative care by the ČSPM ČLS JEP (Czech Society of Palliative Medicine of the Czech Medical Association of J. E. Purkyně) from 2016 (The state of child palliative care in the Czech Republic, 2016). This fact has been confirmed in our research as well. The paediatric palliative care section of the ČSPM ČLS JEP also sets a framework for standards of palliative care in the Czech Republic. In the research, $56.9 \%$ of nurses agreed on the existence of these standards, in the Australian research it was $61 \%$, and $37.5 \%$ of Taiwanese respondents agreed with this statement (Table 5).

It is necessary for the medics to feel supported, to have opportunities to talk about their feelings and share their problems (Kohnerová and Henleyová, 2013). 64.2\% of the Czech respondents agreed with the statement that the medical team expresses their opinions, values and beliefs about providing palliative care - similar to the research from Australia, where $68 \%$ of respondents claimed the same. A noticeable difference was detected in the results of the Taiwanese study, where only $10 \%$ of respondents agreed with the same statement, $25 \%$ did not agree, and $65 \%$ remained neutral.

A significant similarity between the foreign studies was found in the items related to the existence of an adequate team that provides palliative care. In the Czech Republic, $52.3 \%$ confirmed the presence of such experts. In Australia it was 56\%, whilst it was $51.6 \%$ in Taiwan. This fact could be caused by worldwide trends in promoting palliative care that have been noticed in recent years. The optimal model of communication is cooperation and mutual respect. A neonatologist is usually the one who leads the palliative care, although all members of the team should listen to each other, their fears and concerns should be heard and potential misunderstandings should try to be solved (Kain, 2011). The highest level of agreement and highest occurrence of affirmative answers in the examined studies were found within the item dedicated to parents and their opportunity to participate in making decisions about their child. This statement was confirmed by $83.5 \%$ of Czech 
Table 5. Comparison of research results in the Czech Republic, Australia and Taiwan using NiPCAS (in \%)

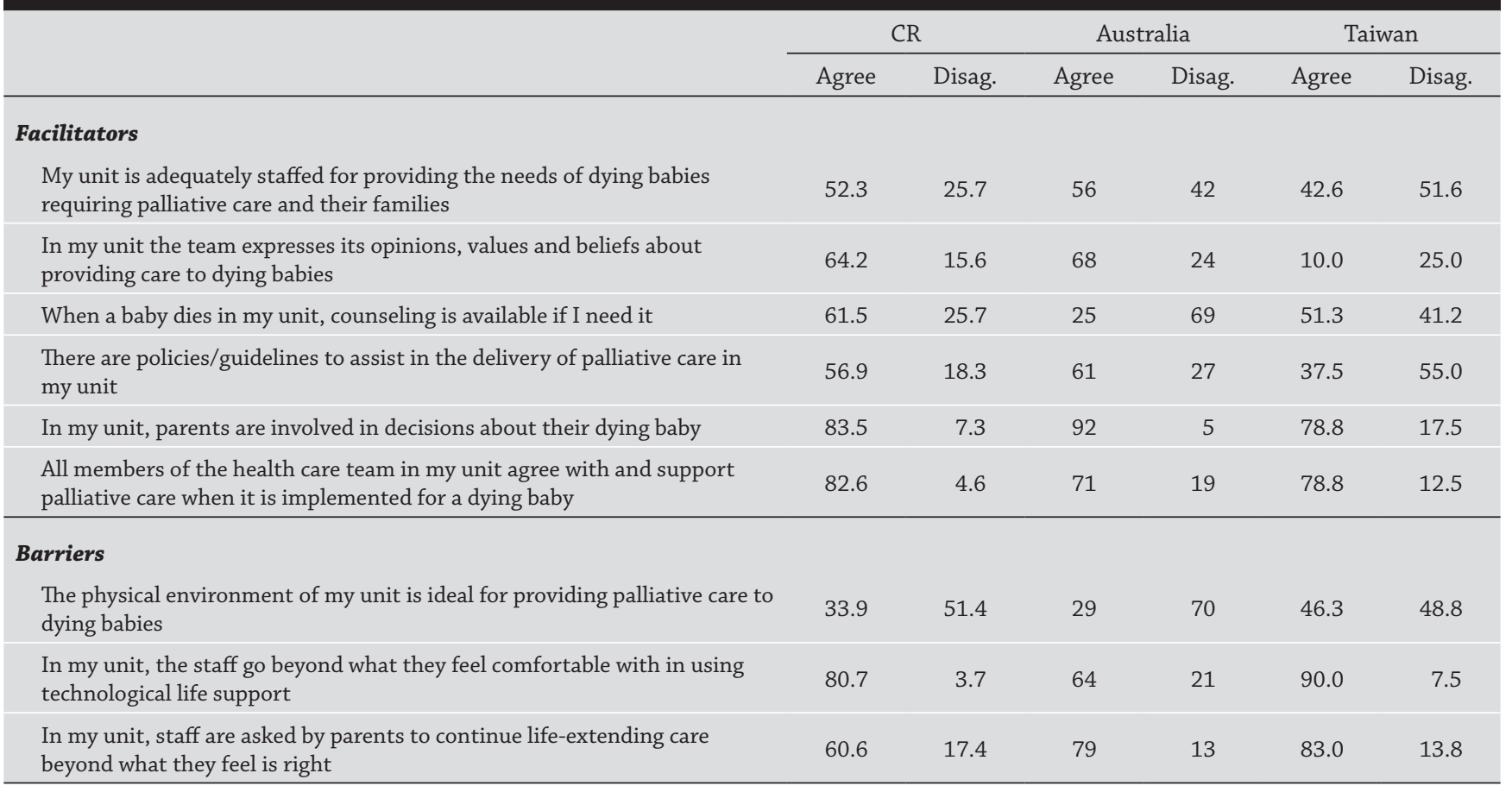

respondents, $92 \%$ of Australian respondents, and $78.75 \%$ of Taiwanese nurses. For this item, according to the nurses, we are close to the goal of perinatal palliative care - the best interests of the child, the child's family, regarding individual needs. The care that parents give to a child during dying is then reflected in the period after death, when families begin to process what happened (Purdy et al., 2017).

\section{Conclusions}

The research showed that nurses working at neonatological intensive care units are experienced with providing dying newborns (and their parents) with palliative care, and that this process is very important. Nevertheless, this result was modestly represented within nurses in the category of under 30 years with less than five years of experience. Nurses that underwent specialist education are more likely to agree that palliative care in neonatology is as important as curative care and they do not feel like they have failed if a baby dies. In providing perinatal palliative care, the facilitators are the support and permission for the treatment across the whole medical team. To provide sensitive and appropriate treatment it is necessary to develop the interdisciplinary practical standards based on evidence that is specific for each institution. One of the main goals of palliative care in nursing should be to pro- vide an effective way of coping with the pain or discomfort of a dying child, and to provide psychosocial, spiritual and cultural support for the family. The facilitator for nurses is also sufficient education leading to the acquisition of skills in empathic communication, care of a grieving family, but also in self-care.

Nurses should be able to recognize barriers that prevent parents from mastering the parent-child bond. The existence of and the opportunity to attend specialized courses for providing newborns with palliative care is an advantage. The presence of a neonatological nurse is indispensable for providing palliative care at the end of a baby's life.

\section{Ethical aspects and conflict of interests}

The authors have no conflict of interests to declare.

\section{Acknowledgements}

I would like to thank all of the participating perinatological centers, colleagues who created the pilot study, and all the people who aim to reach the goals of palliative care and are a real support to parents who go through such a difficult life experience.

\section{Funding}

Supported by the project SGS 11 / LF / 2019-2020 "Problems of perinatal palliative care in the Czech Republic". 


\section{Postoje neonatologických sester k poskytování perinatální paliativní péče}

\section{Souhrn}

Perinatální paliativní péče je poskytována novorozencům, u nichž bylo rozhodnuto neposkytovat život zachraňující péči nebo v život prodlužující péči již nepokračovat. Snahou je zaměřit se na nejlepší zájem dítěte, zlepšit kvalitu života dětí, které jsou v život omezujícím nebo život ohrožujícím stavu. Cílem této studie bylo zjistit postoje sester k poskytování perinatální paliativní péče, identifikovat faktory ovlivňující poskytování paliativní péče na jednotkách intenzivní péče o novorozence v ČR a analyzovat bariéry a facilitátory sester při poskytování perinatální paliativní péče. Byla provedena kvantitativní studie s využitím standardizovaného dotazníku NIPCAS (Neonatal Palliative Care Attitude Scale), adaptovaného do českého jazyka. Výzkum prokázal, že většina účastníků vnímá provádění paliativní péče o umírající děti pozitivně. Byla identifikována bariéra v prostředí, kde je paliativní péče poskytována. Zavedení paliativní péče by mělo zahrnovat informovanost a ujištění rodičů, že zdravotní tým bude i nadále poskytovat tu nejlepší péči o jejich dítě. Rodiče by měli být aktivně zapojeni do rozhodování, vždy s ohledem na jejich emocionální stav, kulturní a náboženské zvyky. Proto by měly existovat specializované vzdělávací kurzy na poskytování paliativní péče u novorozenců.

Klíčová slova: JIP; ošetřovatelská péče; perinatální paliativní péče; sestry

\section{References}

1. Balaguer A, Martín-Ancel A, Ortigoza-Escobar D, Escribano J, Argemi J (2012). The model of palliative care in the perinatal setting: a review of the literature. BMC Pediatr 12: 25. DOI: 10.1186/1471-2431-12-25.

2. Catlin A, Carter B (2002). Creation of a neonatal end-of life palliative care protocol. J Perinatol 22(3): 184-195. DOI: $10.1038 /$ sj.jp.7210687.

3. Chen CHH, Huang LCh, Liu HL, Lee HY, Wu SY, Chang YC, et al. (2013). To Explore the Neonatal Nurses' Beliefs and Attitudes Towards Caring for Dying Neonates in Taiwan. Matern Child Health J 17(10): 1793-1801. DOI: 10.1007/s10995-0121199-0.

4. de Castro de Oliviera F, Cleveland LM, Darilek U, Borges Silva AR, Carmona EV (2018). Brazilian Neonatal Nurses' Palliative Care Experiences. J Perinatal Neonatal Nurs 32(4): E3-E10. DOI: 10.1097/JPN.0000000000000361.

5. Diel PKV, Gomes GC, Xavier DM, dos Santos Savador M, de Oliviera SM (2013). Nurses' Experiences before the death at the neonatal intensive care unit. J Nurs EFPE 7(4): 1081-1089. DOI: 10.5205/r euol.3188-26334-1-LE.0704201302.

6. Fortney CA, Steward, DK (2014). A New Framework to Evaluate the Quality of a Neonatal Death. Death Studies 38(1-5): 294-301. DOI: 10.1080/07481187.2012.742475.

7. Hrdličková L (2019). Sdělování závažných zpráv. In: Bužgová R, Sikorová L, et al. Dětská paliativní péče. Praha: Grada, pp. 121-129.

8. Kain V (2011). Exploring the barriers to palliative care practice in neonatal nursing: a focus group study. Neonatal Paediatric Child Health Nurs 14(1): 9-14.

9. Kain VJ, Wilkinson DJ (2013). Neonatal palliative care in action: moving beyond the rhetoric and influencing policy. J Res Nurs 18(5): 459-468. DOI: 10.1177/1744987113490713.

10. Kain V, Gardner G, Yates P (2009). Neonatal Palliative Care Attitude Scale: Development of an Instrument to Measure the Barriers to and Facilitators of Palliative Care in Neonatal Nursing. Pediatrics 123(2): e207-e213. DOI: 10.1542/ peds.2008-2774.

11. Kenner C, Press J, Ryan D (2015). Recommendations for palliative and bereavement care in the NICU: a family-centered integrative approach. J Perinatol 35(Suppl. 1): S19-S23. DOI: $10.1038 /$ jp.2015.145.
12. Kiman R, Doumic L (2014). Perinatal palliative care: a developing specialty. Int J Palliat Nurs 20(3): 143-148. DOI: 10.12968/ijpn.2014.20.3.143.

13. Kohnerová N, Henleyová A (2013). Když dítě zemře. Praha: Triton, 349 p.

14. Marchuk A (2016). End-of-life care in the neonatal intensive care unit: applying comfort therapy. Int J Palliat Nurs 22(7): 317-323. DOI: 10.12968/ijpn.2016.22.7.317.

15. Purdy IB, Melwak MA, Smith JR, Kenner C, Chuffo-Siewert R, Ryan DJ, et al. (2017). Neonatal Nurses NICU Quality Improvement: Embracing EBP Recommendations to Provide Parent Psychosocial Support. Adv Neonatal Care 17(1): 33-44. DOI: 10.1097/ANC.0000000000000352.

16. Ratislavová K (2016). Perinatální paliativní péče. Praha: Grada, 200 p.

17. Ratislavová K, Hálek J (2019). Specifika paliativní péče v neonatologii. In: Bužgová R, Sikorová L, et al. Dětská paliativní péče. Praha: Grada, pp. 166-188.

18. Reid S, Bredemeyer S, van den Berg C, Cresp T, Martin T, Miara N (2011). Palliative care in the neonatal nursery, Guidelines for neonatal nurses in Australia. Neonatal Paediatr Child Health Nurs 14(2): 2-8.

19. The state of child palliative care in the Czech Republic [Stav dětské paliativní péče v České republice] (2016). Pracovní skupina dětské paliativní péče: Ceské společnosti paliativní medicíny ČLS JEP. [online] [cit. 2021-03-02]. Available from: https://www.paliativnimedicina.cz/wp-content/ uploads/2016/07/zprava-stav-detske-paliativni-peceunor-2016.pdf

20. Whitfield, JM, Siegel RE, Glicken AD, Harmon RJ, Powers LK, Goldson EJ (1982). The application of hospice concepts to neonatal care. Am J Dis Childr 136(5): 421-424. DOI: 10.1001/ archpedi.1982.03970410039009.

21. WHO (2021). Palliative care. [online] [cit. 2021-03-02]. Available from: https://www.who.int/health-topics/palliativecare

22. Wool C (2013). State of the Science on Perinatal Palliative Care. J Obstet Gynecol Neonatal Nurs 42(3): 372-382. DOI: 10.1111/1552-6909.12034.

23. Wool C, Catlin A (2019). Perinatal bereavement and palliative care offered throughout the healthcare system. Ann Palliat Med 8(Suppl. 1): S22-S29. DOI: 10.21037/apm.2018.11.03. 